\title{
E-commerce adoption by SMEs in developing countries: evidence from Indonesia
}

\author{
Rita Rahayu ${ }^{1,2} \cdot$ John Day ${ }^{1}$
}

Received: 31 July 2015/Revised: 1 December 2015/Accepted: 17 January 2016/

Published online: 24 March 2016

(C) The Author(s) 2016. This article is published with open access at Springerlink.com

\begin{abstract}
This study aims to provide an overview of e-commerce adoption by SMEs in developing countries and, in particular, the extent of the adoption of e-commerce by Indonesian SMEs. It identifies the e-commerce benefits realized by these SMEs and investigates the relationship between the levels of e-commerce adoption and the benefits thus realized. The study was motivated by the limited studies related to e-commerce adoption by SMEs, especially in developing countries. In addition, it seems that most e-commerce studies are focused more on upstream issues: to see the factors that facilitate, or barriers faced regarding e-commerce adoption, rather than downstream issues: to see post-adoption benefits. This certainly limits our understanding about e-commerce adoption by SMEs in developing countries, as well as the post-adoption benefits of e-commerce. Indonesia was chosen as the place in which to conduct the study. A survey of 292 SMEs shows that the majority of them are still at an early stage in their adoption of e-commerce. Their use of e-commerce is dominated by marketing and purchasing and procurement activities. "Extending market reach", "increased sales", "improved external communication", "improved company image", "improved speed of processing", and "increased employee productivity" are reported as the top six e-commerce benefits perceived by these SMEs. This study also shows that SMEs at the higher level of e-commerce adoption experience greater e-commerce benefits than those at other levels of adoption.
\end{abstract}

Keywords E-commerce $\cdot$ SMEs $\cdot$ Benefits

Rita Rahayu

aretrahayu@gmail.com; u1067812@hud.ac.uk

1 University of Huddersfield, Queensgate, Huddersfield HD1 3DH, UK

2 Andalas University, Padang, Indonesia 


\section{Introduction}

It is widely recognized that e-commerce technology offers many potential advantages for businesses. The key advantages revealed by the extant e-commerce literature are reduced cost, increased sales, increased productivity, reduced time processing, extended market reach and increased customer loyalty (see, Turban 2010). The advantages offered by e-commerce are believed to be one of the factors that have made e-commerce popular for businesses and this can be seen from the significant growth of e-commerce users year to year. According to the IDC report (2011), in 2009, 624 million internet users had made online purchases with revenue nearly $\$ 8$ trillion in total; and that number was predicted to have increased by yearend 2013 to more than $\$ 16$ trillion of transactions. Such significant growth is also seen in Asia. Based on data reported by The Internet World Statistics (2015), the number of internet users increased dramatically from 2000 to 2015. In June 2015, there were 1.56 billion people in Asia using the internet, whilst in 2000 the number of internet users was only 114 million.

However, the increase of e-commerce use by businesses is mostly being driven by large companies. In comparison with larger companies, the adoption of e-commerce by SMEs relatively lags behind (Govindaraju et al. 2015; Alam et al. 2011; Chiliya et al. 2011).

Researchers have identified many inhibiting factors for the adoption of e-commerce by SMEs, particularly in developing countries. The lack of human resources; internal resistance; unready customers; lack of support; security issues; unready business partners; internal constraints; a lack of IT resources and lack of support were identified by Dubelaar et al. (2005) as major impediments factors of B2C e-business adoption by small businesses. Kotelnikov (2007) also revealed that poor communication infrastructure; lack of ICT knowledge; lack of IT resources; the lack of financial resources and a poor legal infrastructure are some factors that lead to the low adoption of ICT by SMEs in developing countries. A recent study by Jahanshahi and Zhang (2013) also found that security and privacy issues; lack of knowledge and understanding of e-commerce; and high maintenance cost were the main barriers faced by SMEs in three developing countries (Iran, Malaysia and India) in adopting e-commerce. This condition requires attention from many parties, including researchers, given the important role SMEs play in the economic development of a country. They contribute not only in terms of their numbers but also to job creation and poverty reduction (Wit and Kok 2014; Ayyagari et al. 2011; Neumark et al. 2011; Kotelnikov 2007). Therefore, the development of SMEs in a country would have a positive impact on the economic growth of the country, and vice versa.

It is undeniable that there have been many studies conducted regarding e-commerce adoption. However the majority were conducted in developed countries (Kurnia et al. 2015; Williams et al. 2009; Parker and Castleman 2007), and only a few focused on SMEs and in developing countries. This certainly limits the understanding of e-commerce adoption by SMEs, especially in developing countries. In addition, the majority of these previous studies focused predominantly 
on upstream issues where studies tend to report the factors that facilitate (or the barriers faced in regard to e-commerce adoption), rather than downstream, that is those studies that focus on post adoption benefits (Molla and Heeks 2007). Knowing the factors that encourage or inhibit adoption, particularly for SMEs, is important, but understanding how such adoption is beneficial for business performance is also equally important. Salwani et al. (2009) offered three main reasons why SMEs were still reluctant to adopt e-commerce technology, these being the lack of success stories, not having knowledge in e-commerce and lack of information about the potential impact of e-commerce implementation on business performance. Similarly, Kartiwi and MacGregor (2008) reported that one of barriers mentioned by Indonesian SMEs in regard to e-commerce adoption was that "e-commerce does not offer any advantages to our organization". These reasons make many SMEs, especially in developing countries, fearful to invest their resources in this technology.

Therefore, in order to fill this gap, this study aims to provide a better understanding about the adoption of e-commerce by SMEs in developing countries, identifies the e-commerce benefits realized by these SMEs and investigates the relationship between the levels of e-commerce adoption and the benefits realized. Indonesia was chosen as the country in which to conduct the study. There are four reasons for this choice. Firstly, Indonesia is one of the developing countries in Asia and has a large population being the fourth largest population in the world and the largest in Southeast Asia, so therefore, Indonesia might reflect other developing countries in Asia, particularly in Southeast Asia. Secondly, Indonesia is also recognized as the biggest archipelago country in the world, consisting of more than 13 million islands. The huge population and the vast and fragmented geography offer a good reason for businesses in Indonesia, especially SMEs, to adopt e-commerce. Yet, and as commonly found in most developing countries, the adoption of e-commerce by Indonesian SMEs is still lagging behind counterparts in developed countries (Kartiwi and MacGregor 2008). Thirdly, Indonesia is at the heart of Southeast Asia, neighbouring alongside Malaysia, Singapore, China, Japan, and Australia. Finally, Indonesia has recently been identified as one of countries that will become one of the economic powers in this century, together with Mexico, Nigeria and Turkey, popularly known as "MINT" countries (Mexico, Indonesia, Nigeria, and Turkey). MINT was initially popularized by Jim O'Neil in 2013 as a companion to his BRIC countries (Brazil, Russia, India and China). As a country that has been recognized as an important player in the economic world, it is particularly interesting to study e-commerce adoption in this country.

\section{Literature review}

There is no single definition of e-commerce with various definitions being offered by several authors. Turban (2010) defined e-commerce as "the process of buying, selling, transferring, or exchanging products, services, and/or information via computer networks, mostly Internet and intranets". While, Tagliavini et al. (2001) argued that any economic activity conducted via the internet can be called 
e-commerce. In more detail, Clarke (2005) elaborated the detailed elements of e-commerce as: "support services for trading... encompass(ing) inter-organizational email, directories, trading support systems for commodities, products, customized goods and services, management information, and statistical reporting systems". Even though the definitions vary in exact detail, it can be seen from the definitions above that the use of ICT, particularly internet technology, is a main component of e-commerce. Hence in this study the definition of e-commerce refers to the use of networked information and communication technologies (ICT), especially Internet technology, in any business activities.

According to Turban (2010), the transition of traditional commerce to electronic commerce depends on the level of digitisation of the products/services sold, the process, and the delivery methods. If the digital element is found in any one of those then it can be said that the e-commerce exists, but only partial e-commerce. Whilst if all of these elements are digital, then it is considered as pure e-commerce. Buying a mobile phone from http://www.apple.com is one example of partial e-commerce, because there are physical dimensions to this transaction which are product and the delivery method. However, buying software from http://www.amazon.com is the example of pure e-commerce, because all of dimensions are digital (product, process and delivery method).

It cannot be denied that the e-commerce technology was originally developed to meet the needs of large enterprises in developed countries. However, the application of e-commerce is still suitable for SMEs in developing countries. E-mail, websites, internet, intranet, extranet, Electronic Data Interchange (EDI), Electronic Fund Transfer (EFT) and barcode are some of basic e-commerce technologies that are most likely relevant for the SME (Kurnia et al. 2015; Morteza et al. 2011; Mustaffa and Beaumont 2004; Abell and Lim 1996).

The use of these technologies by SMEs is variable. Abell and Lim (1996) found that SMEs in New Zealand used the internet in order to communicate with internal and external parties, get information from suppliers, provide information, conduct R\&D activities, to be seen at the forefront of technology, to do market and product research, place orders to suppliers, and take orders from customers. Drew (2003) found also that e-mail and intranet applications were used by SMEs for internal communication; whilst web sites were used to advertise, promote, recruit, and for procurement. In addition, Daniel and Wilson (2002) mentioned that e-commerce technologies assist SMEs in a wide range of activities, which are: providing information about the company, providing information about goods and services offered, taking and placing orders, receiving payment, delivering goods and services, after sales service or contact, identifying suppliers, purchasing inventory and non-inventory, communicating with internal and external parties, exchanging document and design with customers or suppliers, searching the information, advertising and recruitment activities. The breadth of e-commerce use in business activities reflects the level of e-commerce adoption where the wider the use of e-commerce the higher level of e-commerce adoption. The wider the scope of e-commerce use in businesses, the more likely the realization of even greater commerce benefits (Zhu and Kraemer 2005). 
In order to explain the level of e-commerce adoption, the concept of "stage of growth" or growth models are often used in previous studies. This concept recognized that information system(s), including e-commerce, in an organization are not fixed but experience several levels of development. Information System literature recorded several growth models developed by previous researchers. The first growth model was developed by Richard L. Nolan during the 1970s, which is well known as "Nolan's stages of growth model". In this model, there are six stages faced by the firm in respect of information system usage, namely: initiation, contagion, control, integration, data administration and maturity. Each stage has different features, and all of them will exist together.

Then, Rao et al. (2003) proposed four stages-presence, portal, transaction integration, and enterprises integration, to illustrate the evolution of e-commerce in an organization. Each stage has different characteristics and different problems, and Fig. 1 shows the detail of this model.

In this model, the subsequent stage is better than previous stage. Even though the evolution is described sequentially, there is no necessity for a business to start from the beginning stage (presence stage). Business can start from any stage.

In line with this, Prananto et al. (2003) also proposed six stages of e-commerce development (see Fig. 2), which are no presence, static online, interactive online, e-commerce, internal integration, and external integration. This model links the level of e-commerce adoption with the investment required and its potential benefit.

Consistent with Rao et al. (2003) and Prananto et al. (2003) also mentioned that the characteristics of each stage are different and business can start the adoption in any level of the stages. Figure 2 above shows that a higher level of e-commerce adoption will require greater investment and that more benefits will be gathered.

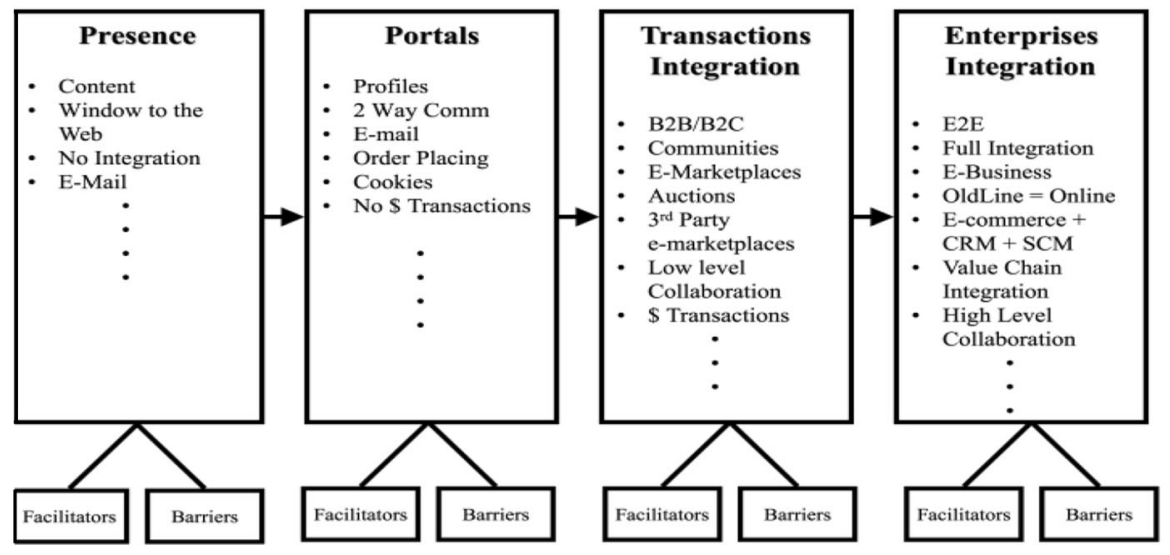

Fig. 1 Stages model. Source Rao et al. (2003) 


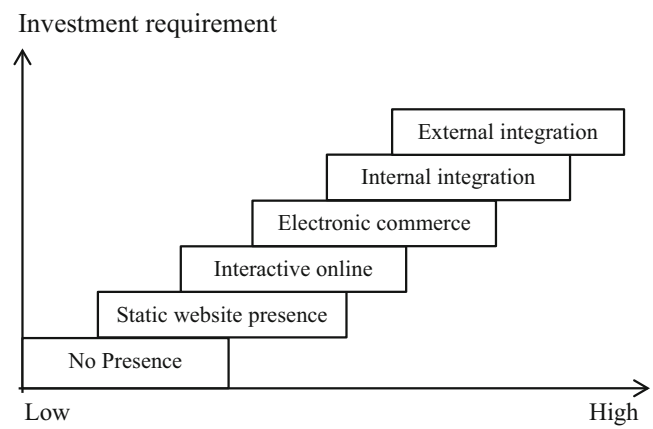

Fig. 2 E-business stages of growth model. Source Prananto et al. (2003: 11)

Table 1 E-commerce benefits

\begin{tabular}{ll}
\hline No. & E-commerce benefits \\
\hline 1 & Increased revenue \\
2 & Reduced operation cost \\
3 & Reduced cost of purchasing and procurement \\
4 & Reduced marketing costs \\
5 & Increased customer loyalty and retention \\
6 & Reduced complain from client \\
7 & Improved supplier relationship \\
8 & Improved competitive position \\
9 & Extending market reach \\
10 & Improved speed of processing \\
11 & Improved external communication \\
12 & Improved company image \\
13 & Improved internal communication \\
14 & Increased employee's satisfaction \\
15 & Increased employee's productivity \\
\hline
\end{tabular}

As mentioned previously, there are many potential benefits offered by e-commerce. Based on a review of previous studies, fifteen benefits of e-commerce are identified in this study. They are presented in Table 1.

\section{Methodology}

In this study, an online questionnaire survey method was applied. The online questionnaire was chosen because this method is considered to have several advantages, which are that it is cheaper, better (in term of response rate), faster and easier than conventional methods (Fricker and Schonlau 2002). The questionnaire for this study consisted of three main parts. The first part relates to the current 
condition of e-commerce adoption by the SMEs: their level of adoption, length of adoption, number of IT staff and scope of e-commerce use. Regarding the level of e-commerce adoption, in this study six levels of e-commerce adoption were proposed, which are: no internet/no email (stage zero), e-mail but no websites (stage 1), static website (stage 2), interactive websites but no transaction (stage 3), websites which allow business transaction (stage 4), and integrated websites (stage 5). The second part is about the benefits of e-commerce adoption realized by the SMEs following adoption. In this part, the respondents were asked about their perception of the fifteen e-commerce benefits (shown in Table 1) by responding to a five-point Likert-scale, ranging from 1 (strongly agree) to 5 (strongly disagree). However, for consistency of measurement, in the further analysis, the score of respondents' perceptions was re-coded, in with a score of 1 for strongly disagree to 5 for strongly agree. Then, the last part of questionnaire is about demographic factors, such as age, education, type of industry and firm size.

\subsection{Sampling method}

In this study, SMEs are defined as businesses which have less than 100 employees, assets less than IDR 10 billion, and total sales per year below IDR 50 billion. There is no centralized SME database available in Indonesia. Most of the data related to SMEs is collected and stored by parties who are interested in the SME. For example, the Indonesian government via the Indonesian Ministry of Cooperative and Empowerment of Small Medium Enterprises (Kementrian Koperasi dan Usaha Kecil Menengah Republik Indonesia) provides some SME data in specific areas. The data provided by this ministry can be accessed through several websites: http:// www.depkop.go.id, http://www.jakarta.go.id, and http://promoukm.com. Besides government, other parties such as research institutes and private organization also provide SME data, such as http://www.smartbisnis.co.id, http://bisnisukm.com, http://www.indotrading.com, http://www.indonetwork.co.id. In this study, a combination of government sources and the private organization sources was used to determine the sample frame. In order to ensure there were no overlapping SMEs on the sample frame, the list of SMEs was sorted alphabetically by company name. Only the firms which had complete information were considered as part of the sample. By complete information, we mean that the information about the company name, company address, e-mail address and contact number, type of industry, owners, and number of employees were available. After identifying and cleaning the database, 3267 SMEs were chosen as the sampling frame. All SMEs on the database were at least 5 years old.

The respondents in this study are the SME owner or manager. There were 3267 questionnaires sent to respondents through e-mail. Two hundred and ninety-two fully completed, and hence, usable questionnaires were analysed. The profiles of the SMEs and respondents who participated in this study are presented in Table 2. 
Table 2 Profile of the SMEs and respondents

\begin{tabular}{|c|c|c|}
\hline & Frequency & $\%$ \\
\hline \multicolumn{3}{|l|}{ Industry type } \\
\hline Agriculture & 6 & 2.1 \\
\hline Manufacture & 71 & 24.3 \\
\hline Electronic, gas and water supply & 1 & 0.3 \\
\hline Construction & 5 & 1.7 \\
\hline Trade, hotel and restaurant & 152 & 52.1 \\
\hline Transport and communication & 2 & 0.7 \\
\hline Finance, rent and service & 53 & 18.2 \\
\hline Others & 2 & 0.7 \\
\hline Total & 292 & 100.0 \\
\hline \multicolumn{3}{|l|}{ Firm size } \\
\hline Micro & 100 & 34.2 \\
\hline Small & 144 & 49.3 \\
\hline Medium & 48 & 16.4 \\
\hline Total & 292 & 100.0 \\
\hline \multicolumn{3}{|l|}{ Respondent's gender } \\
\hline Male & 211 & 72.3 \\
\hline Female & 81 & 27.7 \\
\hline Total & 292 & 100.0 \\
\hline \multicolumn{3}{|l|}{ Respondent's age } \\
\hline Under 25 years old & 32 & 11.0 \\
\hline 25-34 years old & 115 & 39.4 \\
\hline $35-44$ years old & 111 & 38.0 \\
\hline $45-55$ years old & 31 & 10.6 \\
\hline Above 55 years old & 3 & 1.0 \\
\hline Total & 292 & 100.0 \\
\hline \multicolumn{3}{|l|}{ Respondent's education } \\
\hline Junior high school & 6 & 2.1 \\
\hline Senior high school & 52 & 17.8 \\
\hline Diploma & 52 & 17.8 \\
\hline Undergraduate & 162 & 55.5 \\
\hline Master & 18 & 6.2 \\
\hline Doctoral & 2 & 0.7 \\
\hline Total & 292 & 100.0 \\
\hline
\end{tabular}

\section{Results}

\subsection{The adoption of e-commerce by SMEs in Indonesia}

The questionnaire results show that among the 292 SMEs who participated in this study, 21 of them $(7.2 \%)$ have not connected to the internet and they do not have an e-mail; while the others (271 SMEs or $92.8 \%$ ) have. The former, in this study, are 
Table 3 The level of e-commerce adoption: Indonesian SMEs

\begin{tabular}{lcr}
\hline & Frequency & $\%$ \\
\hline Non adopters & 21 & 7.2 \\
E-mail & 64 & 21.9 \\
Static website & 95 & 32.5 \\
Interactive website & 73 & 25.0 \\
E-commerce & 38 & 13.0 \\
Internal integration & 1 & 0.3 \\
Total & 292 & 100.0 \\
\hline
\end{tabular}

Table 4 The length of e-commerce adoption by SMEs in Indonesia

\begin{tabular}{lllllr}
\hline & \multicolumn{2}{l}{ Time } & Total \\
\cline { 2 - 5 } & Less than 1 year & 2 or 3 years & 4 or 5 years & More than 5 \\
\hline E-mail & 13 & 27 & 11 & 13 & 64 \\
Static website & 12 & 54 & 18 & 11 & 95 \\
Interactive website & 25 & 35 & 9 & 4 & 73 \\
E-commerce & 9 & 20 & 6 & 3 & 38 \\
Internal integration & 1 & 0 & 0 & 31 & 271 \\
Total & 60 & 136 & 44 & 0 & 1 \\
\hline
\end{tabular}

classified as non e-commerce adopters, whilst the latter are classified as e-commerce adopters. For the e-commerce adopters, 64 of them $(21.9 \%)$ are in stage 1;95 SMEs $(32.5 \%)$ are in stage 2; 73 SMEs $(25 \%)$ are in stage 3; 38 SMEs (13\%) are in stage 4 and only $1 \mathrm{SME}$ is in stage 5 . For more details, Table 3 presents the current stage of e-commerce adoption by these SMEs in more detail.

The length of e-commerce adoption by Indonesian SMEs varies. Table 4 presents the length of e-commerce adoption by these Indonesian SMEs.

It can be seen that the adoption of e-commerce by Indonesian SMEs is relatively new. Most of them have adopted this technology for less than 3 years, and only a few of them have adopted e-commerce for more than 5 years.

Table 5 Number of IT staff

\begin{tabular}{lrrrrr}
\hline & \multicolumn{2}{l}{ IT staff } & & Total \\
\cline { 2 - 5 } & None & $1-2$ people & $3-5$ people & More than 5 people \\
\hline E-mail & 23 & 29 & 10 & 2 & 64 \\
Static website & 31 & 49 & 10 & 5 & 95 \\
Interactive website & 17 & 43 & 10 & 3 & 73 \\
E-commerce & 4 & 26 & 7 & 1 & 38 \\
Internal integration & 0 & 1 & 37 & 11 & 1 \\
Total & 75 & 148 & & & 271 \\
\hline
\end{tabular}


Table 6 The use of e-commerce technologies by SMEs in Indonesia

\begin{tabular}{lcl}
\hline Activities & Number of SMEs & $\%$ \\
\hline Logistic and distribution activities & 61 & 22.5 \\
Financial activities & 68 & 25.1 \\
Purchasing and procurement activities & 88 & 32.5 \\
Operational and Processing activities & 47 & 17.1 \\
Marketing activities & 233 & 86 \\
After sales services activities & 68 & 25.1 \\
\hline
\end{tabular}

In regard to IT staff, this study found that 75 SMEs do not employ IT staff, 148 SMEs have employed one, or two, IT staff; thirty-seven SMEs have employed 3-5 IT staff; and only eleven SMEs have more than five IT staff. Table 5 shows the number of IT staff employed by SMEs in Indonesia.

The use of e-commerce technologies by SMEs in Indonesia varies. However, the majority of them use those technologies in marketing activities. Table 6 shows the use of e-commerce technologies by SMEs in Indonesia.

\subsection{The e-commerce benefits realized by the SMEs}

Table 7 presents the responses given in regard to e-commerce adoption.

\subsection{The level of e-commerce adoption and the e-commerce benefits}

In order to identify the benefits realized by Indonesian SMEs at each level of e-commerce adoption, the mean scores for each benefit realized by the SMEs in each level is counted. In this process, due to the limited numbers of participants in the internal integration group (only one participant), this group was merged into the e-commerce level category. As a result, in the further analysis, the level of e-commerce adoption consists of four levels, which are: e-mail, static website, interactive website, and e-commerce (Table 8).

Table 8 shows that the mean scores for each benefit as perceived by the SMEs in different levels of e-commerce adoption are varied, starting from the lowest, 3.34, to the highest, 4.62 .

The top benefits with the highest mean score reported by the SMEs in each group are:

From the scores reported in Table 9, it can be shown that there are six e-commerce benefits, which are extending market reach (benefit i), increased sales (benefit a), improved external communication (benefit k), improve company image (benefit 1), improved speed processing (benefit $\mathrm{j}$ ), and increased employee productivity (benefit o), that are consistently perceived with a high score by SMEs in each level/group, (above 4 on the five point Likert scale). In addition, it seems that the mean scores of these six benefits reported by the SMEs tend to increase by the increase in the level of e-commerce adoption. For example, the mean score of extending market reach (benefit $\mathrm{i}$ ) reported by the SMEs in e-mail adopters is 4.32 , 
Table 7 Responses on the benefits of e-commerce

\begin{tabular}{llcccc}
\hline & $\begin{array}{l}\text { Strongly } \\
\text { agree } \\
\text { and agree }\end{array}$ & $\begin{array}{l}\text { Neutral } \\
\end{array} \quad \begin{array}{l}\text { Disagree and } \\
\text { strongly } \\
\text { disagree }\end{array}$ & Mean & $\begin{array}{l}\text { Standard } \\
\text { deviation }\end{array}$ \\
\hline Increased sales (a) & 251 & 24 & 2 & 4.37 & 0.662 \\
Reduced operation cost (b) & 193 & 59 & 25 & 3.86 & 0.898 \\
Reduced cost of purchasing and & 139 & 96 & 42 & 3.48 & 0.985 \\
$\quad$ procurement (c) & 206 & 48 & 23 & 3.88 & 0.898 \\
Reduced marketing costs (d) & 178 & 83 & 15 & 3.78 & 0.810 \\
Increased customer loyalty and retention (e) & 136 & 109 & 32 & 3.48 & 0.852 \\
Reduced complain from client (f) & 176 & 83 & 18 & 3.75 & 0.815 \\
Improved supplier relationship (g) & 211 & 54 & 12 & 3.94 & 0.751 \\
Improved competitive position (h) & 264 & 11 & 1 & 4.49 & 0.545 \\
Extending market reach (i) & 221 & 46 & 7 & 4.13 & 0.730 \\
Improved speed of processing (j) & 238 & 32 & 6 & 4.16 & 0.677 \\
Improved external communication (k) & 245 & 29 & 2 & 4.29 & 0.643 \\
Improved company image (l) & 208 & 62 & 6 & 4 & 0.729 \\
Improved internal communication (m) & 175 & 95 & 7 & 3.83 & 0.780 \\
Increased employee's satisfaction (n) & 228 & 42 & 7 & 4.09 & 0.734 \\
Increased employee's productivity (o) & & & & & \\
\hline
\end{tabular}

while the mean scores reported by static adopters and interactive adopters are 4.54 and 4.62. A similar pattern is also found for benefits: a, $1, \mathrm{k}, \mathrm{j}$ and $\mathrm{o}$.

Even though the mean scores for these benefits tend to increase by the increase in the level of e-commerce adoption, this does not mean that the increase is statistically significant. To determine whether these scores are statistically significant or not, an ANOVA test was conducted.

The results of ANOVA test for the six benefits are shown in Tables 10 and 11.

Information provided in Table 10 is used to identify whether a variant on scores of each of the four groups are equal or not. In this case, it is desired that the variance of scores are equal because one of basic assumptions to conduct a One Way ANOVA is homogeneity of variance. According to Pallant (2013), if the significance value is greater than 0.05 , it means there is a homogeneity of variance, however if the significance value is less than 0.05 , it means that there are differences between variances in population. Based on Table 10, it can be seen that the significance value of homogeneity test for all benefits are greater than 0.05 . These values show that the assumption of homogeneity of variance is met.

In order to determine whether the mean scores given by each groups are different statistically and significantly, the significant value provided in Table 11 can be used. If the significance value is less than 0.05 , it means that the differences on mean scores of dependent variables are statistically significant, however, in contrast if the significance value is greater than 0.05 , it means that the differences on mean scores are not statistically significant. Table 11 shows that the significance values of all benefits are less than 0.05 , except for benefit $\mathrm{k}$ with a significance value of 0.463 . This means that there are significant differences between the mean scores of all 


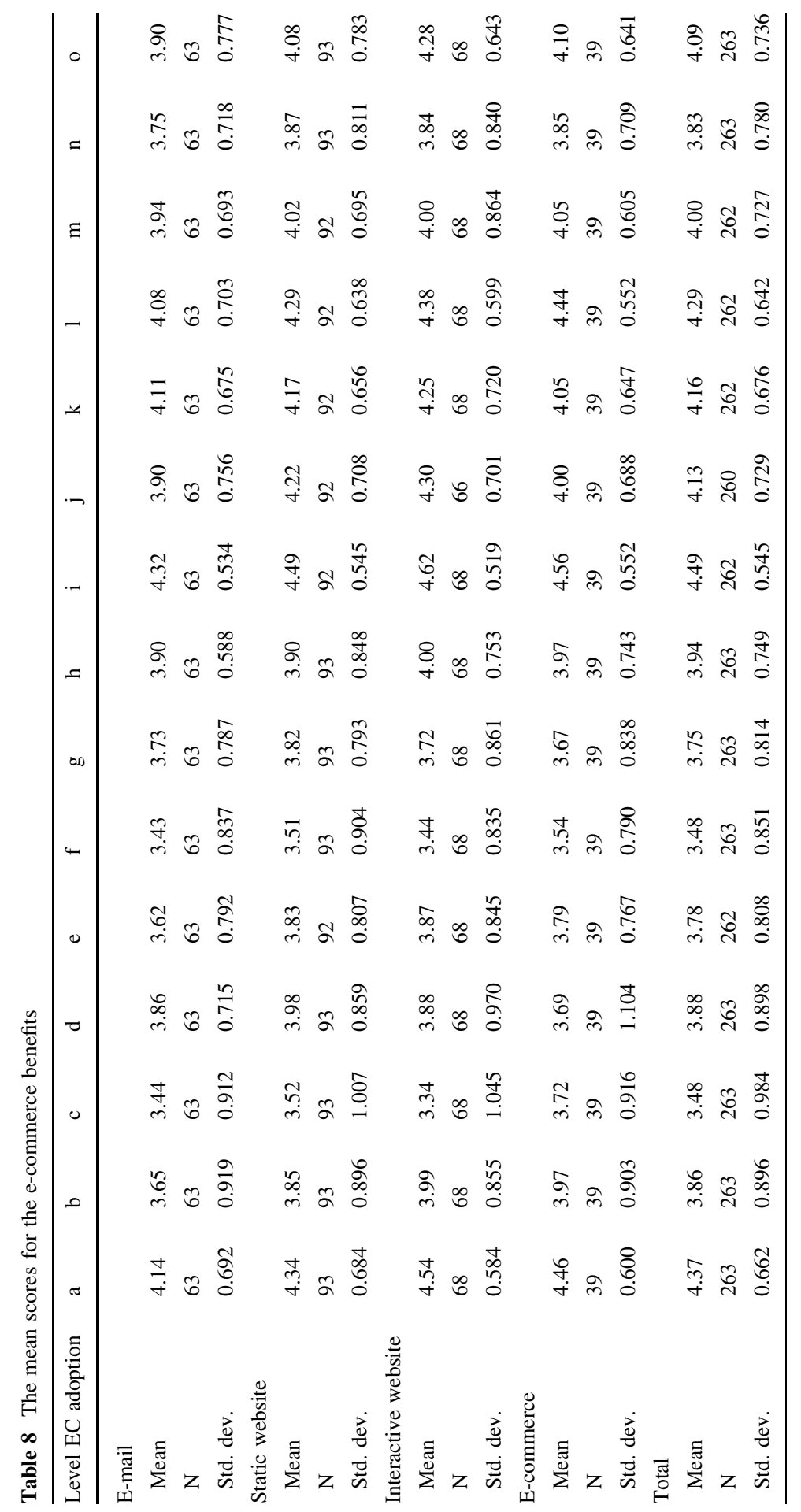


Table 9 Top benefits reported by SMEs in each group

\section{A. E-mail group adopter}

Benefit i: extending market reach

Benefit a: increased sales

Benefit k: improved external communication

Benefit 1: improve company image

4.08

\section{B. Static website}

Benefit i: extending market reach

Benefit a: increased sales

Benefit 1: improve company image

Benefit j: Improved speed processing

4.22

Benefit k: improved external communication

\section{Interactive website}

Benefit i: extending market reach

Benefit a: increased sales

Benefit 1: improve company image

Benefit j: Improved speed processing

Benefit o: increased employee's productivity

D. Transactive/e-commerce group

Benefit i: extending market reach

Benefit a: increased sales

Benefit 1: improve company image

Benefit o: increased employee's productivity

Benefit k: improved external communication

Table 10 Test of homogeneity of variances

\begin{tabular}{lllll}
\hline & Levene statistic & df1 & df2 & Sig. \\
\hline Benefit_a & 0.747 & 3 & 259 & 0.525 \\
Benefit_i & 1.036 & 3 & 258 & 0.377 \\
Benefit_j & 1.873 & 3 & 256 & 0.135 \\
Benefit_k & 1.943 & 3 & 258 & 0.123 \\
Benefit_1 & 0.400 & 3 & 258 & 0.753 \\
Benefit_o & 0.396 & 3 & 259 & 0.756 \\
\hline
\end{tabular}

benefits except for benefit $\mathrm{k}$. This implies that the benefits perceived by SMEs tend to increase along with the increasing of the level of e-commerce adoption.

\section{Analysis and discussion}

This study has provided an overview of the adoption of e-commerce by SMEs in developing countries. By using Indonesian SMEs as a sample, the results of this study show that the majority of SMEs in Indonesia are still at the lower level of 
Table 11 ANOVA

\begin{tabular}{|c|c|c|c|c|c|}
\hline & Sum of squares & df & Mean square & $\mathrm{F}$ & Sig. \\
\hline \multicolumn{6}{|l|}{ Benefit_a } \\
\hline Between groups & 5.695 & 3 & 1.898 & 4.500 & 0.004 \\
\hline Within groups & 109.263 & 259 & 0.422 & & \\
\hline Total & 114.958 & 262 & & & \\
\hline \multicolumn{6}{|l|}{ Benefit_i } \\
\hline Between groups & 3.196 & 3 & 1.065 & 3.700 & 0.012 \\
\hline Within groups & 74.288 & 258 & 0.288 & & \\
\hline Total & 77.485 & 261 & & & \\
\hline \multicolumn{6}{|l|}{ Benefit_j } \\
\hline Between groups & 6.534 & 3 & 2.178 & 4.255 & 0.006 \\
\hline Within groups & 131.020 & 256 & 0.512 & & \\
\hline Total & 137.554 & 259 & & & \\
\hline \multicolumn{6}{|l|}{ Benefit_k } \\
\hline Between groups & 1.180 & 3 & 0.393 & 0.859 & 0.463 \\
\hline Within groups & 118.087 & 258 & 0.458 & & \\
\hline Total & 119.267 & 261 & & & \\
\hline \multicolumn{6}{|l|}{ Benefit_1 } \\
\hline Between groups & 4.203 & 3 & 1.401 & 3.498 & 0.016 \\
\hline Within groups & 103.328 & 258 & 0.400 & & \\
\hline Total & 107.531 & 261 & & & \\
\hline \multicolumn{6}{|l|}{ Benefit_o } \\
\hline Between groups & 4.627 & 3 & 1.542 & 2.912 & 0.035 \\
\hline Within groups & 137.183 & 259 & 0.530 & & \\
\hline Total & 141.810 & 262 & & & \\
\hline
\end{tabular}

e-commerce adoption. It can be seen that most of them adopt only simple websites, such as a static website or interactive website; and, even more, some of them only have e-mail. Comparing with the SMEs in developed countries, this condition is certainly still far behind. However, if it is compared with other developing countries, such as, Brazil, Malaysia, Portugal and South Africa, a similar condition is commonly found (Gonçalves et al. 2010; Lin and Lee 2005; Molla and Licker 2004; Tigre 2003).

Pointing to the length of e-commerce adoption, this study shows that majority of the Indonesian SMEs (72.32 \%) have adopted e-commerce for 3 years or less, while $27.68 \%$ of them have adopted e-commerce for more than 4 years. Even though e-commerce technology was introduced in Indonesia in 1996, this technology has only been widely known about in recent years. This explains why adoption appears to a relatively recent phenomenon. According to the International Communication Union (2007), in 2007 the average values of some indicators of ICT development in Indonesia were still far behind the average values of Asia and the world. In addition to this, the Nielson Global online survey conducted in 2008 showed that Indonesia 
was on the bottom position in Asia Pacific in terms of on-line transaction 3 (13th from 14 countries). However, this position has changed significantly since 2010 . At that time, the Indonesian government through the Ministry of Communication and Information Technology (Kementrian Komunikasi dan Informatika) issued a policy regarding the provision of affordable internet access for rural communities by relying on satellite connections (Donny 2014).

Due to the low level of e-commerce adoption by SMEs in Indonesia, it is not surprising to see that $54.6 \%$ of SMEs just have one or two IT specialists. This might be for several reasons. Firstly, it because the scope of business of Indonesian SMEs is not too broad, and the business activities are not too complex, they do not require a lot of IT specialists. Secondly, it might also be that many SMEs cannot afford their own IT specialists so they outsource, or hire temporary IT staff, or purchase IT solutions. Thirdly, it might also be that many IT solutions are relatively user friendly and intuitive to learn and so that non IT specialists are able to deliver them. Also $27.6 \%$ of SMEs reported that they do not have an IT employee. A lack of financial resources is likely to be a reason for this and so those owners who have enough IT knowledge usually acted as their own IT staff.

In regard to the use of e-commerce technologies by SMEs in Indonesia, the result of this study shows that majority of SMEs use e-commerce technology for marketing purposes or in marketing activities. This is reasonable because most of the SMEs who participated in this study are website adopters (static or interactive).

The top six e-commerce benefits reported by SMEs in Indonesia are: extending market reach, increased sales, improved external communication, improved company image, improved speed processing and increased employee's productivity. The mean scores of these six benefits reported by the SMEs tend to increase along with the increase of the level of e-commerce adoption. Based on the ANOVA test, it was found that the significance value of all of the top six benefits, except improved external communication, is below 0.05, which means that the SMEs in each level of e-commerce adoption perceived these benefits differently. In this regard, the higher the level of e-commerce adoption, the more benefits realized by the SMEs. This finding is consistent with the stages of growth model proposed by Prananto et al. (2003). In this model, the benefits of e-commerce gathered by businesses depend on the level of e-commerce adoption where the higher the level of e-commerce adoption the more sophisticated the technology infrastructure required, and the greater the benefits that will be gathered. This finding also supports the [Kraemer et al. (2002)] study.

\section{Conclusion}

This study provides an understanding about the adoption of e-commerce by SMEs in developing countries, especially in Indonesia. This study shows that the adoption of e-commerce by SMEs in a developing country, especially in Indonesia, is still at a low level. Most of them are e-mail and website adopters (both static and interactive website). Comparing to SMEs in developed countries, the level of e-commerce adoption by the Indonesian SMEs lags far behind. This condition 
certainly has implications for the government to further increase their efforts through promoting effective programmes and initiatives to encourage the level of e-commerce adoption by Indonesian SMEs.

This study also provides empirical support that the e-commerce provides many benefits for SMEs. The top six benefits reported by Indonesian SMEs are extending their market reach, increased sales, improvements external communication, company image, speed of data processing, and employee productivity. This result could enrich the understanding of SME owners about the potential benefits of e-commerce. A greater understanding about this will increase their probability to allocate some resources towards adopting e-commerce.

In addition, this study also shows that the benefits realized by SMEs tend to be increased by the increase in the level of e-commerce adoption. This condition certainly can be a consideration for SME owners in adopting e-commerce and this also will be useful for SME owner in deciding whether to move forward to the next stage or not.

Open Access This article is distributed under the terms of the Creative Commons Attribution 4.0 International License (http://creativecommons.org/licenses/by/4.0/), which permits unrestricted use, distribution, and reproduction in any medium, provided you give appropriate credit to the original author(s) and the source, provide a link to the Creative Commons license, and indicate if changes were made.

\section{References}

Abell, W., \& Lim, L. (1996). Business use of the Internet in New Zealand: an exploratory study (Vol. September 1996). New Zealand: Linconln University.

Alam, S. S., Ali, M. Y., \& Jani, M. F. M. (2011). An empirical study of factors affecting electronic commerce adoption among SMEs in Malaysia. Journal of Business Economics and Management, 12(2), 375-399.

Ayyagari, M., Demirguc-Kunt, A., \& Maksimovic, V. (2011). Small vs. Young Firms across the World, contribution to employment, job creation and growth (F. a. P. S. D. Team, Trans.) (pp. 41): The World Bank Development Research Group.

Chiliya, N., Chikandiwa, C., Afolabi, B. (2011). Factors Affecting Small Micro Medium Enterprises'(SMMEs) Adoption of E-Commerce in the Eastern Cape Province of South Africa. International Journal of Business and Management, 6(10), 28-36.

Clarke R. (2005). The Past, Present and Future of B2C eCommerce. Statement for a Panel Session, Sydney. http://www.rogerclarke.com/EC/B2C-0509.html

Daniel, E., \& Wilson, H. (2002). Adoption intentions and benefits realised: a study of e-commerce in UK SME. Journal of Small Business and Enterprise Development, 9(4), 331-348. doi:10.1108/ 14626000210450522.

Donny, B.U. (2014). Catatan Ringkas Tata Kelola \& Praktik Internet Indonesia. Indonesia: ICT watch Indonesia.

Drew, S. (2003). Strategic uses of e-commerce by SMEs in the east of England. European Management Journal, 21(1), 79-88.

Dubelaar, C., Sohal, A., \& Savic, V. (2005). Benefits, impediments and critical success factors in B2C E-business adoption. Technovation, 25(11), 1251-1262.

Fricker, R. D., \& Schonlau, M. (2002). Advantages and disadvantages of Internet research surveys: evidence from the literature. Field Methods, 14(4), 347-367.

Gonçalves, R., Santos, S. S., \& Morais, E. P. (2010). E-Business maturity and information technology in Portuguese SMEs. Communications of the IBIMA, 2010, 8. 
Govindaraju, R., Wiratmadja, I. I., \& Rivana, R. (2015). Analysis of drivers for e-commerce adoption by SMEs in Indonesia. Paper presented at the Interdisciplinary Behavior and Social Sciences: Proceedings of the International Congress on Interdisciplinary Behaviour and Social Sciences 2014.

Jahanshahi, A. A., \& Zhang, S. X. (2013). E-commerce for SMEs: empirical insights from three countries. Journal of Small Business and Enterprise Development, 20(4), 849-865. doi:10.1108/ JSBED-03-2012-0039.

Kartiwi, M., \& MacGregor, R. C. (2008). Electronic Commerce adoption barriers in small to mediumsized enterprises (SMEs) in developed and developing countries: a cross-Country comparison. Journal of Electronic Commerce in Organization, 5(3), 35-51.

Kotelnikov, V. (2007). Small and medium Enterprises and ICT: Asia-Pacific Development Information Programme, e-Primers for the Information Economy, Society and Polity, (APCICT) 2007

Kraemer, K. L., Dedrick, J., Dunkle, D. (2002). E-commerce: a mile wide and an inch deep. Center for Research on Information Technology and Organizations. Irvine: University of California

Kurnia, S., Choudrie, J., Mahbubur, R. M., Alzougool, B. (2015). E-commerce technology adoption: a Malaysian grocery SME retail sector study. Journal of Business Research, 68(9), 1906-1918.

Lin, H.-F., \& Lee, G.-G. (2005). Impact of organizational learning and knowledge management factors on e-business adoption. Management Decision, 43(2), 171-188.

Molla, A., \& Heeks, R. (2007). Exploring E-Commerce benefits for businesses in a developing Country. The Information Society, 23(2), 95-108. doi:10.1080/01972240701224028.

Molla, A., \& Licker, P. S. (2004). Maturation stage of e-commerce in developing countries: a survey of South African companies. Information Technologies \& International Development, 2(1), 89-98.

Morteza, G., Daniel, A.-A., \& Jose, B.-A. (2011). Adoption of e-commerce applications in SMEs. Industrial Management \& Data Systems, 111(8), 1238-1269. doi:10.1108/02635571111170785.

Mustaffa, S., \& Beaumont, N. (2004). The effect of electronic commerce on small Australian enterprises. Technovation, 24(2), 85-95.

Neumark, D., Wall, B., \& Zhang, J. (2011). Do small businesses create more jobs?: new evidence for the United States from the national establishment time series. The Review of Economics and Statistics, 93(1), 16-29. doi:10.1162/REST_a_00060.

Pallant, J. (2013). SPSS survival manual: a step by step guide to data analysis using IBM SPSS. Maidenhead: McGraw-Hill.

Parker, C., \& Castleman, T. (2007). New directions for research on SME-eBusiness: insights from an analysis of journal articles from 2003-2006. Journal of Information Systems and Small Business, 1(1), 21-40.

Prananto, A., McKay, J., \& Marshall, P. (2003). A study of the progression of e-business maturity in Australian SMEs: Some evidence of the applicability of the stages of growth for e-business model. Proceedings of the PACIS, Adelaide, pp. 68-80.

Rao, S. S., Metts, G., \& Monge, C. A. M. (2003). Electronic commerce development in small and medium sized enterprises: a stage model and its implications. Business Process Management Journal, 9(1), 11-32.

Salwani, M. I., Marthandan, G., Norzaidi, M. D., \& Chong, S. C. (2009). E-commerce usage and business performance in the Malaysian tourism sector: empirical analysis. Information Management \& Computer Security, 17(2), 166-185.

Tagliavini, M., Ravarini, A., \& Antonelli, A. (2001). An evaluation model for electronic commerce activities within SMEs. Information Technology and Management, 2(2), 211-230. doi:10.1023/a: 1011417703063.

Tigre, P. B. (2003). Brazil in the age of electronic commerce. The Information Society, 19(1), 33-43.

Turban, E. (2010). Electronic commerce 2010: a managerial perspective. Upper Saddle River: Pearson Education.

Williams, M. D., Dwivedi, Y. K., Lal, B., \& Schwarz, A. (2009). Contemporary trends and issues in IT adoption and diffusion research. Journal of Information Technology, 24(1), 1-10.

Wit, G., \& Kok, J. (2014). Do small businesses create more jobs? New evidence for Europe. Small Business Economics, 42(2), 283-295. doi:10.1007/s11187-013-9480-1.

Zhu, K., \& Kraemer, K. L. (2005). Post-adoption variations in usage and value of e-business by organizations: cross-country evidence from the retail industry. Information Systems Research, 16(1), 61-84. 